\title{
ZASTOSOWANIE CROWDFUNDINGU W SZKOLNICTWIE WYŻSZYM
}

\begin{abstract}
The use of crowdfunding in higher education

The paper presents crowdfunding platforms dedicated to higher education institutions. Examples of projects submitted by academics are presented. The areas of application of crowdfunding in higher education are described.
\end{abstract}

Keywords: crowdfunding, higher education

\section{Streszczenie}

W opracowaniu przedstawiono platformy crowdfundingowe przeznaczone dla instytucji szkolnictwa wyższego. Zaprezentowano przykłady projektów zgłaszanych przez przedstawicieli środowisk akademickich. Opisano także obszary zastosowania crowdfundingu w szkolnictwie wyższym.

Słowa kluczowe: crowdfunding, szkolnictwo wyższe

\section{Wprowadzenie}

Rozwój technologii internetowych oraz postępująca globalizacja w gospodarce zmieniają funkcjonowanie rynku finansowego, co przejawia się np. w rozwijających się internetowych usługach finansowych, w tym alternatywnych, bez udziału instytucji finansowych. Przykładem alternatywnego sposobu finansowania jest crowdfunding, który zrodził się w obszarze łączącym usługi finansowe, sieci społeczne, Internet oraz koncepcję Web 2.0. Crowdfunding wspiera finansowanie gospodarki zarówno przez uzupełnianie tradycyjnych źródeł finansowania podmiotów gospodarczych, jak i przez dotowanie projektów kreatywnych oraz innowacyjnych, szczególnie narażonych na problemy związane z dostępem do funduszy. Projekty te są finansowane przez wiele drobnych, jednorazowych 
wpłat dokonywanych przez osoby zainteresowane projektem, które w ten sposób nagradzają dobre pomysły, kreatywność, innowacyjność oraz wiarygodność ich autorów.

Instytucje szkolnictwa wyższego, zwłaszcza w Stanach Zjednoczonych, powoli włączają crowdfunding do tradycyjnych źródeł finansowania. Coraz częściej publikowane są raporty potwierdzające, że crowdfunding to znaczące nowe źródło pozyskiwania środków finansowych zarówno na badania naukowe, jak i na inicjatywy edukacyjne.

Cele artykułu zostały określone jako:

- zdefiniowanie terminu „crowdfunding” oraz przedstawienie jego różnych modeli,

- zdefiniowanie terminu „crowdfunding” w szkolnictwie wyższym,

- identyfikacja platform crowdfundingowych umożliwiających pozyskiwanie funduszy w Polsce,

- identyfikacja platform crowdfundingowych przeznaczonych dla instytucji szkolnictwa wyższego oraz środowisk akademickich,

- przedstawienie możliwości zastosowania crowdfundingu przez instytucje szkolnictwa wyższego oraz środowiska akademickie.

W celu zbadania crowdfundingu w szkolnictwie wyższym wybrana została metoda jakościowa, jaką jest analiza treści wybranych serwisów internetowych.

Artykuł składa się z sześciu części. W pierwszej zaprezentowano crowdfunding i jego rodzaje. W drugiej przedstawiono metodę badań. Następnie przybliżono platformy crowdfundingowe funkcjonujące w Polsce. W kolejnych częściach scharakteryzowano platformy przeznaczone dla instytucji szkolnictwa wyższego oraz opisano obszary zastosowania crowdfundingu w szkolnictwie wyższym.

\section{Crowdfunding i jego rodzaje}

Termin „crowdfunding” w tłumaczeniu z języka angielskiego oznacza gromadzenie środków finansowych z (internetowego) „tłumu”. Polskie określenie tego fenomenu to „finansowanie społecznościowe”.

Crowdfunding to różnorodny zbiór strategii i mechanizmów wspierających działalność fundraisingową przez innowacyjne i przedsiębiorcze projekty oraz przedsięwzięcia [Sidman, 2015]. Dariusz Dziuba przedstawia podejścia do definiowania crowdfundingu (internetowego) w ujęciu szerokim, zgodnie z którym można go interpretować jako niemal dowolną formę gromadzenia środków finansowych przez sieć komputerów, oraz w wąskim, uwypuklającym proces, w którym np. przedsiębiorcy, osoby fizyczne czy organizacje non profit zbierają środki finansowe na różne projekty dzięki wsparciu wielu osób ofiarowujących na nie pieniądze [Dziuba, 2012]. Autor ten proponuje następującą definicję crowdfundingu:

- to proces realizowany w środowisku internetowym, aktywizowany poprzez otwarte zgłoszenie oferty (celu przedsięwzięcia, projektu), polegający na groma- 
dzeniu wolnych środków finansowych spośród potencjalnie ogromnej liczby rozproszonych uczestników (ich „tłumu”);

- gromadzenie zasobów finansowych może być dokonywane w formie bezzwrotnej donacji wynikającej z celów charytatywnych, motywów filantropijnych albo płatności w oczekiwaniu na nagrodę rzeczową bądź na potrzeby możliwości pożyczania zasobów w przyszłości, albo - jak w przypadku systemów inwestycyjnych - inwestycji w określone przedsięwzięcia (firmy, zwłaszcza we wstępnej fazie rozwoju) w oczekiwaniu na gratyfikacje finansowe i udziały w zyskach czy akcje;

- zakres korzyści wynika z zastosowanego modelu crowdfundingu i stosowanej strategii nagradzania uczestników [Dziuba, 2012: 85-86].

W opinii autorki powyższa definicja D. Dziuby wydaje się najbardziej adekwatna w kontekście szkolnictwa wyższego.

Biorąc pod uwagę charakter projektu, na którego realizację zbierane są fundusze, wyróżnić można [Hemer, 2011]:

- projekty non profit, które mają na celu realizację społecznych celów (np. w obszarze zdrowia publicznego, publicznych projektów badawczych),

- projekty komercyjne (np. wydanie płyty, książki),

- projekty „pośrednie”, których nie można wyraźnie przypisać do żadnej z powyższych kategorii, ponieważ nie jest to wiadome na wstępnym etapie poszukiwania finansowania (np. niezależne albumy muzyczne i filmy, występy artystyczne).

Zgodnie z klasyfikacją modeli finansowania społecznościowego odnoszącą się do różnych metod pozyskiwania funduszy wskazać można [UKIE Crowd Funding Report..., 2012]:

- model donacyjny (darowizn), najczęściej oparty na przekazywaniu darczyńcom nagród pozafinansowych,

- model kredytowy (pożyczkowy), w którym fundatorzy uzyskują zwrot pożyczki wraz z odsetkami,

- model inwestycyjny (współfinansowania przedsięwzięć) lub akcyjny, uwarunkowany możliwością otrzymywania przez fundatorów części zysków.

W innym zestawieniu modeli crowdfundingu, w zależności od rodzaju korzyści, jakie twórca chce zaproponować wspierającym, oraz od charakteru zbiórek, wyróżnić można finansowanie nieudziałowe oraz udziałowe. Finansowanie nieudziałowe to najczęściej spotykana forma, mająca charakter przedsprzedażowy. W tym modelu wyszczególnia się dwa podejścia: ,wszystko albo nic” (finansowane są tylko te projekty, które uzbierają oczekiwaną kwotę w określonym czasie, w innym przypadku fundusze są zwracane fundatorom) oraz ,bierzesz, ile zbierzesz" (projekty realizowane są niezależnie od osiągnięcia lub nie celu finansowego). W przypadku finansowania udziałowego w zamian za przekazanie odpowiedniej sumy na realizację projektu osoba wspierająca uzyskuje korzyść, najczęściej udziały lub akcje firmy.

Karol Król [www 1] zwraca uwagę, że w różnych definicjach finansowania społecznościowego można wskazać pewne jego cechy, które umożliwiają odróżnienie go od zbiórek publicznych czy tradycyjnych darowizn. Wśród nich wymienia 
fakt, że crowdfunding opiera się na płatności bezgotówkowej, a pozyskanie kapitału odbywa się na korzystniejszych warunkach niż na ogólnodostępnym ryn$\mathrm{ku}$. Ponadto przeznaczenie środków finansowych oraz efekty ich wydatkowania są jasno określone. Co więcej, do informacji o projekcie ma dostęp bardzo duże grono osób, a możliwość dofinansowania projektu jest przedstawiana w sposób otwarty, z uwzględnieniem świadczeń zwrotnych. Proces ten jest możliwy dzięki wykorzystaniu rozwiązań teleinformatycznych.

Crowdfunding jest rodzajem crowdsourcingu (obok crowd creation, crowd voting, crowd wisdom), choć obecnie bywa postrzegany jako niezależne zjawisko [Kozioł-Nadolna, 2015]. Warto nadmienić w tym miejscu, że całkowity globalny rynek crowdfundingu oszacowany przez wielkość zbiórki pieniędzy w 2015 roku wyniósł 34,4 mld dolarów (w tym: w modelu pożyczkowym zebrano 25,1 mld dolarów, w modelu opartym na darowiznach, nieudziałowym 5,5 mld dolarów, w inwestycyjnym 2,6 mld dolarów, w pozostałych modelach 1,2 mld dolarów) [Crowdfunding Industry Statistics 2015 2016].

Przedmiotem rozważań w niniejszym opracowaniu będzie donacyjny, nieudziałowy model crowdfundingu, który jest najczęściej wykorzystywany przez instytucje szkolnictwa wyższego oraz środowiska akademickie.

Na podstawie definicji finansowania społecznościowego D. Dziuby można przyjąć, że crowdfunding w szkolnictwie wyższym to proces realizowany w internecie przez szkołę wyższą lub przedstawicieli środowiska akademickiego z wykorzystaniem technologii teleinformatycznych, aktywizowany przez otwarte zgłoszenie projektu, najczęściej edukacyjnego lub badawczego, polegający na gromadzeniu środków finansowych od interesariuszy szkoły wyższej w formie bezzwrotnej donacji.

\section{Metoda badań}

W celu zbadania zagadnienia crowdfundingu w szkolnictwie wyższym wybrana została metoda jakościowa, jaką jest analiza treści wybranych serwisów internetowych. Badaniu podlegały treści zawarte na polskich platformach crowdfundingowych oraz treści zamieszczone na platformach crowdfundingowych przeznaczonych dla szkolnictwa wyższego, które funkcjonują w USA. Przeprowadzona analiza treści umożliwiła udzielenie odpowiedzi na pytania badawcze.

Wojciech Czakon zauważa, że badania interpretatywne (potocznie nazywane jakościowymi) nakierowane są na zrozumienie wybranego fragmentu rzeczywistości. „Zrozumienie dotyczy tego, w jaki sposób uczestnicy badanej rzeczywistości jej doświadczają, jak w niej uczestniczą, jak ją kształtują i interpretują" [Czakon, 2015: 95]. David Silverman konstatuje, że badania jakościowe służą odpowiedziom na pytania: ,jak?”, „dlaczego?”, „w jaki sposób?” i mają charakter wyjaśniający [Silverman, 2008].

W przypadku badań jakościowych istnieje wiele możliwości dotyczących procedury badawczej. Wynika to z faktu, że najczęściej analiza danych odbywa się 
równolegle z procesem pisania, a poszczególne analizowane przypadki mogą być badane i analizowane w nieco inny sposób [Czernek, 2015]. Procedura badawcza rozpoczyna się od określenia problemu badawczego.

W niniejszej pracy postawiono następujące pytania badawcze:

- Czy istnieja platformy crowdfundingowe przeznaczone dla instytucji szkolnictwa wyższego oraz środowisk akademickich?

- Jakie przykładowe projekty zgłaszają na platformach crowdfundingowych przedstawiciele środowisk akademickich?

- W jaki sposób crowdfunding może być wykorzystany przez instytucje szkolnictwa wyższego oraz środowiska akademickie?

Następnym etapem procedury badawczej było dokonanie przeglądu literatury. Choć nieliczne prace na temat crowdfundingu powstają od kilku lat [Méric i in., 2016; Freedman, Nutting, 2015; Awdziej i in., 2016; Lenart-Gansiniec, 2016, 2017; Pieniążek, 2014; Dziuba, 2012; Kozioł-Nadolna, 2015; Król, 2013], jest to nadal mało poznany obszar nauki.

W kolejnym etapie prowadzonych badań zidentyfikowano platformy crowdfundingowe działające w Polsce, a następnie podjęta została próba znalezienia platform przeznaczonych dla instytucji szkolnictwa wyższego w Polsce oraz w USA.

Później treści zawarte na platformach poddano analizie. W rezultacie jej przeprowadzenia rozpoznano przykładowe projekty zgłaszane na platformach przez przedstawicieli środowisk akademickich oraz określono, także na podstawie przeglądu literatury, potencjalne obszary zastosowania crowdfundingu w szkolnictwie wyższym.

\section{Platformy crowdfundingowe w Polsce}

Finansowanie społecznościowe jest pozyskiwane przez elektroniczne (internetowe) platformy crowdfundingowe, których funkcją jest m.in. prezentowanie ofert projektów, tworzenie interakcji pomiędzy fundatorami a projektodawcami, umożliwianie dokonywania płatności oraz kontrolowanie przebiegu tych działań.

W Polsce większość platform finansowania społecznościowego powstała po 2011 roku. Pierwszą platformą typu nieudziałowego „wszystko albo nic”, działającą na podstawie nagród, był portal PolakPotrafi.pl. Dotychczas (stan na 7.11.2017) użytkownicy wsparli na nim różne projekty kwotą przekraczającą 19,5 mln zł [www 2]. Platforma ta przeznaczona jest dla osób, które poszukują środków finansowych, aby realizować ciekawe przedsięwzięcia i urzeczywistniać kreatywne pomysły.

Innym przykładem jest platforma Beesfund. Jest to alternatywa dla małych i średnich przedsiębiorstw, które szukają wsparcia finansowego - do 400 tys. zł na rozwój przedsiębiorstwa. Emisja na platformie Beesfund niesie dla przedsiębiorcy wiele korzyści, m.in. budowanie społeczności inwestorów wokół firmy, możliwość przeprowadzenia kampanii marketingowej oraz dokonania wyceny wartości biznesu [www 3]. 
Największa w Polsce platforma pomagania Siepomaga.pl realizuje projekty charytatywne. Głównym jej celem jest stworzenie możliwie największej społeczności ludzi wrażliwych na bliźnich i zwierzęta. Łączne wpłaty od użytkowników przekroczyły kwotę $170 \mathrm{mln}$ zł (stan na 7.11.2017) [www 4].

Ponadto w Polsce działaja platformy:

- Crowdangels.pl, dzięki której przedsiębiorcy mogą pozyskiwać kapitał w zamian za udziały w przedsięwzięciu,

- Fans4Club, przeznaczona jest dla klubów sportowych i kibiców,

- Fundujesz.pl, przeznaczona dla trzeciego sektora,

- MegaTotal.pl, będąca społecznościową wytwórnią muzyczną,

- Mintu.me, integrująca rynek produktów i usług ekologicznych,

- OdpalProjekt.pl, funkcjonująca w ramach modelu „,bierzesz, ile zbierzesz”,

- Wspieramkulture.pl, ukierunkowana na projekty kulturalne,

- Wspieram.to, wspierająca osoby kreatywne.

\section{Platformy przeznaczone dla instytucji szkolnictwa wyższego w Polsce}

Przeprowadzone badanie nie wykazało, aby w Polsce istniały elektroniczne platformy crowdfundingowe specjalnie przeznaczone dla instytucji szkolnictwa wyższego oraz środowisk akademickich. Wprawdzie na platformach PolakPotrafi.pl oraz Wspieram.to istnieją kategorie projektów „edukacja”, ale nie zidentyfikowano projektów zgłoszonych przez szkoły wyższe lub na ich rzecz.

Jeśli chodzi o działalność indywidualnych przedstawicieli środowisk akademickich, to jako przykład można wskazać „Projekt Asasif - tajemnice egipskich grobowców". Była to inicjatywa wrocławskich badaczy reprezentujących różne dziedziny nauki, którzy chcieli wyjaśnić tajemnice egipskich grobowców. Ostatecznie projekt nie został zrealizowany, gdyż nie uzyskał pełnego finansowania [www 5].

Innym przykładem projektu związanego ze środowiskiem akademickim jest „Wydanie książki Pokolenie Erasmusa”, będącej prawdziwą historią studenckiej wymiany we Włoszech. Celem autorki było zachęcenie młodych ludzi do korzystania z wymian i projektów międzynarodowych. Projekt wsparły 93 osoby. Zebrano $6472 \mathrm{zł} \mathrm{z} \mathrm{planowanych} 6000 \mathrm{zł} \mathrm{(107 \% )} \mathrm{[www} \mathrm{6].}$

Ciekawą inicjatywą, sfinansowaną z nadwyżką, była zbiórka pieniędzy na internetowe pismo naukowe „Praktyka Teoretyczna”. Autorzy ubiegali się o kwotę 7500 zł na wydanie trzech numerów czasopisma naukowego. Dzięki 124 osobom wspierającym udało się zebrać 8107 zł [www 7]. 


\section{Platformy przeznaczone dla instytucji szkolnictwa wyższego w USA}

Pierwsza w Stanach Zjednoczonych platforma crowdfundingowa stworzona dla instytucji szkolnictwa wyższego, Microryza, powstała w 2012 roku i została następnie przekształcona w Experiment. Umożliwia ona naukowcom publikowanie informacji o projektach badawczych w celu pozyskania funduszy na ich realizację. Jest to platforma typu nieudziałowego ,wszystko albo nic". W zamian za otrzymane środki naukowcy zobowiązani są do dzielenia się wynikami przeprowadzonych badań. Badacze czynią to zwykle, udostępniając recenzowane publikacje w czasopismach, materiały konferencyjne, plakaty akademickie czy otwarte zbiory danych. Projekty na platformie są prezentowane w 20 kategoriach (m.in. ekonomia, nauki społeczne, biologia). Wszystkie są rygorystycznie recenzowane przed ich opublikowaniem. Dotychczas (stan na 10.11.2017) ufundowano 743 projekty badawcze. Lącznie zostały one wsparte przez ponad 40 tys. osób w kwocie przekraczającej 7,5 mln dolarów [www 8].

Przykładem przedsięwzięcia, które zostało sfinansowane na platformie Experiment w kategorii ekonomia, jest projekt zatytułowany „W jaki sposób przedsiębiorstwa naprawiają swoją reputację po skandalach?". Celem projektu było zbadanie, jak firma może wykorzystać różne strategie, aby skutecznie naprawić postrzeganie całej branży po kryzysie w innej, powiązanej firmie. Autor projektu ubiegał się o 1300 dolarów (uzyskał 115\% tej kwoty), które planował przeznaczyć na przeprowadzenie badań ankietowych [www 9].

Innym rozwiązaniem, wdrożonym przez wiele uniwersytetów amerykańskich, jest zakup platformy crowdfundingowej takiej jak GiveCampus, ScaleFunder lub USEED. Są to produkty typu white label, co oznacza, że są dostosowywane przez dostawców do wymagań uczelni i oferowane z jej logo. W tym rozwiązaniu zwykle $100 \%$ zebranych funduszy trafia do autorów projektów.

Platformy przedstawione w tabeli 1 mogą być wykorzystywane zarówno przez studentów, nauczycieli akademickich, jak i przez poszczególne jednostki uczelni (np. do przeprowadzania kampanii mających na celu gromadzenie funduszy na rzecz szkoły wyższej).

Dzięki platformie GiveCampus studenci na kierunku wokalistyka chóralna w Missouri State University zebrali fundusze niezbędne do tego, aby pokryć koszty organizacji koncertu oraz zakupić wyposażenie chóralne. Początkowo planowano zebrać 13,5 tys. dolarów, a ostatecznie udało się zebrać 50 tys. dzięki hojności ponad 250 darczyńców z całego świata [www 10].

Za pomocą platformy ScaleFunder środowisko akademickie związane z Uniwersytetem Kalifornijskim pozyskało środki finansowe na przeniesienie trzytonowego wieka trumny z pochówku Psamtika, naczelnego lekarza w starożytnym Egipcie, z magazynu do muzeum oraz na wykonanie multimedialnej ekspozycji; wszystko w ramach projektu „Pomóż najstarszemu egipskiemu lekarzowi dostać się do muzeum". Początkowy cel finansowy został ustalony na poziomie 20 tys. 
Tabela 1

Platformy crowdfundingowe w USA przeznaczone dla instytucji szkolnictwa wyższego

\begin{tabular}{|c|l|}
\hline Nazwa & \multicolumn{1}{c|}{ Opis } \\
\hline GiveCampus & $\begin{array}{l}\text { Platforma pomagająca w pozyskiwaniu funduszy w obszarze edukacyjnym, która } \\
\text { umożliwia instytucjom szkolnictwa wyższego nawiązanie kontaktu z interesariu- } \\
\text { szami. Absolwenci, studenci, rodzice, wykładowcy i pozostali pracownicy mogą } \\
\text { dzięki niej nawiązywać i utrzymywać kontakt z uczelnią oraz wspierać jej różno- } \\
\text { rodne działania. Każda szkoła wyższa ustala własne wytyczne dotyczące tego, kto } \\
\text { i na jakich zasadach może utworzyć kampanię crowdfundingową. Platforma jest } \\
\text { nabywana oraz zarządzana przez uczelnię }\end{array}$ \\
\hline ScaleFunder & $\begin{array}{l}\text { Platforma pozwalająca na gromadzenie funduszy przez angażowanie społeczności, } \\
\text { ukierunkowana na pozyskiwanie nowych darczyńców. ScaleFunder ukazuje uni- } \\
\text { katową tożsamość instytucji szkolnictwa wyższego. Platforma jest nabywana oraz } \\
\text { zarządzana przez uczelnię i to władze uczelni podejmują decyzję, na jakich zasa- } \\
\text { dach można prezentować projekty szerokiemu gronu potencjalnych darczyńców }\end{array}$ \\
\hline USEED & $\begin{array}{l}\text { Platforma umożliwiająca gromadzenie środków finansowych od stron zaintereso- } \\
\text { wanych funkcjonowaniem szkoły wyższej. Studenci, wykładowcy czy absolwenci } \\
\text { stają się adwokatami uczelni, którzy pomagają w pozyskiwaniu darowizn zarówno } \\
\text { od wewnętrznej społeczności, jak i od osób spoza uczelni }\end{array}$ \\
\hline
\end{tabular}

Źródło: opracowanie własne na podstawie: https://www.givecampus.com/, http://www.scalefunder.com/, https://useed.net/ [dostęp: 6.11.2017].

dolarów, a ostatecznie udało się pozyskać kwotę 30903 dolarów (154\% zakładanej kwoty) od 122 darczyńców [www 11].

Naukowcy z University of Washington za sprawą platformy USEED zgromadzili fundusze na budowę regionalnego centrum modelowania klimatu. Zaplanowano, że w centrum będą prowadzone badania, aby określić zmiany klimatyczne spowodowane emisją gazów cieplarnianych. Dotychczas (stan na 16.11.2017) zebrano 11625 dolarów, co stanowi 23\% pożądanej kwoty, ale zbiórka nie została jeszcze zakończona [www 12].

Przedstawione platformy przeznaczone dla instytucji szkolnictwa wyższego w USA nie są jedynym rozwiązaniem, z którego mogą korzystać przedstawiciele środowisk akademickich. Do „ogólnych” platform crowdfundingowych dających sposobność pozyskiwania funduszy na projekty edukacyjne lub badawcze należą: Kickstarter, Indiegogo, StayClassy, FirstGiving, RocketHub, Classy, Crowdrise, GoFundMe czy Razoo.

\section{Obszary zastosowania crowdfundingu w szkolnictwie wyższym}

Crowdfunding może być stosowany przez instytucje szkolnictwa wyższego oraz środowiska akademickie w celu gromadzenia funduszy na różnorodne projekty, najczęściej edukacyjne lub badawcze. Może także być użyteczny w pozyskiwaniu 
zasobów finansowych na działalność uczelni (choć dotyczy to głównie uniwersytetów amerykańskich ${ }^{1}$ ).

Crowdfunding może być ważnym źródłem finansowania szeroko rozumianych projektów edukacyjnych, takich jak: opłacanie czesnego, stypendia, tworzenie uczelnianych pracowni komputerowych, finansowanie strojów uczelnianych drużyn sportowych, wycieczek terenowych, zakup książek do biblioteki, wsparcie dla programów wymiany studentów, letnie staże [Solemon i in., 2013]. Za sprawą finansowania społecznościowego studenci mają możliwość gromadzenia pieniędzy na zakup książek, pokrycie kosztów wynajęcia mieszkania, wyjazd na staż czy opłacenie nauki języków obcych.

Również sfera badań naukowych jest obszarem, w którym coraz częściej wykorzystywane jest finansowanie społecznościowe. W ramach wszystkich rozstrzygniętych przez Narodowe Centrum Nauki konkursów w 2016 roku złożono prawie 10 tys. wniosków na sumę ok. 4,8 mld zł. Do finansowania zakwalifikowano niespełna 2,5 tys. z nich, na kwotę ponad 1,1 mld zł. Łączny wskaźnik sukcesu wyniósł 25\% [Statystyki konkursów 2016, 2017]. Oznacza to, że 75\% projektów nie zostało sfinansowanych i nie jest wykluczone, że większość z nich nigdy nie będzie zrealizowana. Crowdfunding może być alternatywnym źródłem finansowania dla takich właśnie projektów. Naukowcy mogą ubiegać się o fundusze na przeprowadzenie eksperymentów, badań pilotażowych, udział w konferencjach naukowych, wydanie publikacji, szczególnie książek.

Crowdfunding może także być użyteczny w pozyskiwaniu zasobów finansowych na działalność uczelni, np. na tworzenie i wyposażanie uczelnianych pracowni, organizowanie wydarzeń edukacyjnych (festiwali nauki, dni przedsiębiorczości) i kulturalnych (koncertów), organizowanie zjazdów absolwentów i jubileuszy, utrzymanie i remontowanie obiektów szkoły wyższej czy pokrywanie kosztów funkcjonowania wydawnictw uczelnianych.

$\mathrm{Z}$ pewnością przedstawione przykłady to zaledwie niewielka część możliwych obszarów zastosowania crowdfundingu w szkolnictwie wyższym.

\section{Zakończenie}

Przeprowadzone badanie nie wykazało, aby w Polsce istniały elektroniczne platformy crowdfundingowe przeznaczone szczególnie dla instytucji szkolnictwa wyższego oraz środowisk akademickich. Można jednak wskazać wiele przykładów indywidualnej działalności przedstawicieli środowisk akademickich mającej na celu pozyskanie funduszy na projekty na platformach „ogólnych”. Wiele platform przeznaczonych dla szkolnictwa wyższego istnieje natomiast w USA. Do najbardziej znanych należą: Experiment, GiveCampus, ScaleFunder lub USEED.

${ }^{1}$ Przykładowo Uniwersytet Harvarda w 2016 roku pozyskał łącznie ze wszystkich źródeł 1,19 mld dolarów. Źródło: https:/www.insidehighered.com/news/2017/02/07/growth-charitable-contributions-colleges-slows-2016 [dostęp: 16.11.2017]. 
Crowdfunding jest w przypadku uczelni amerykańskich i może stać się dla polskich szkół wyższych ważnym źródłem zasobów finansowych. To, że włączanie go do tradycyjnych źródeł finansowania przebiega powoli, często jest spowodowane obawami związanymi z korzystaniem z usług zewnętrznego dostawcy, zarządzaniem technologią, niezdolnością do monitorowania przepływu darowizn, koniecznością prowadzenia korespondencji, kosztami czy ilością czasu potrzebnego na wdrożenie systemu.

W opracowaniu przedstawiono liczne przykłady projektów zgłaszanych na platformach crowdfundingowych przez przedstawicieli środowisk akademickich. Wskazano także obszary zastosowania crowdfundingu w szkolnictwie wyższym. Finansowanie społecznościowe może być użyteczne w procesie gromadzenia funduszy na różnorodne projekty, edukacyjne oraz badawcze. Może również być przydatne w pozyskiwaniu zasobów finansowych na działalność uczelni.

Podsumowując, należy podkreślić, że finansowanie społecznościowe może stanowić znaczące wsparcie dla instytucji szkolnictwa wyższego oraz środowisk akademickich pod względem zwiększenia dostępu do finansowania. Korzyści z wykorzystywania crowdfundingu w szkolnictwie wyższym mogą uzyskać wszystkie grupy, zarówno donatorzy, jak i obdarowani, a zakres tych korzyści uzależniony jest od stosowanego modelu crowdfundingu. Tymczasem idea społecznego finansowania edukacji i nauki musi w Polsce dopiero się rozwinąć.

\section{Bibliografia}

Awdziej M., Krzyżanowska M., Tkaczyk J. (2016), Motywowanie do wspóltworzenia wartości - rozważania na przykładzie platformy crowdfundingowej „Polakpotrafi.pl”, „Nierówności Społeczne a Wzrost Gospodarczy”, 45.

Crowdfunding Industry Statistics 2015 2016, Massolution Crowdfunding Industry 2015 Report, http://crowdexpert.com/crowdfunding-industry-statistics/ [dostęp: 9.11.2017].

Czakon W. (2015), Rygor metodologiczny [w:] W. Czakon (red.), Podstawy metodologii badań w naukach o zarzqdzaniu, Oficyna a Wolters Kluwer business, Warszawa.

Czernek K. (2015), Wprowadzenie do badań jakościowych [w:] W. Czakon (red.), Podstawy metodologii badań w naukach o zarzadzaniu, Oficyna a Wolters Kluwer business, Warszawa.

Dziuba D. (2012), Rozwój systemów crowdfundingu-modele, oczekiwania i uwarunkowania, „Problemy Zarządzania”, 10(3).

Freedman D.M., Nutting M.R. (2015), Equity Crowdfunding for Investors: A Guide to Risks, Returns, Regulations, Funding Portals, Due Diligence, and Deal Terms, Wiley \& Sons, Hoboken (N.J.).

Hemer J. (2011), A Snapshot on Crowdfunding, Working Papers Firms and Region, No. R2/2011, Fraunhofer ISI, Karlsruhe, http://www.legalefiscale.it/wp-content/uploads/2016/09/StudioCrowdfundig.pdf [dostęp: 7.11.2017].

Kozioł-Nadolna K. (2015), Crowdfunding jako źródło finansowania innowacyjnych projektów, „Zeszyty Naukowe Uniwersytetu Szczecińskiego. Finanse, Rynki Finansowe, Ubezpieczenia”, 73 (854): Ryzyko, zarzadzanie, wartość, 671-683. 
Król K. (2013), Crowdfunding. Od pomystu do biznesu, dzięki społeczności, Crowdfunding.pl, Warszawa.

Lenart-Gansiniec R. (2016), Crowd Capital: Conceptualisation Attempt, „International Journal of Contemporary Management", 15(2).

Lenart-Gansiniec R. (2017), Zaufanie a crowdsourcing w organizacjach publicznych, „Organizacja i Kierowanie", 2(176).

Méric J., Maque I., Brabet J. (2016), International Perspectives on Crowdfunding: Positive, Normative and Critical Theory, Emerald Group Publishing Limited, Bingley (UK).

Pieniążek J. (2014), Najnowsze trendy i kierunki rozwoju finansowania społecznościowego, „Marketing Instytucji Naukowych i Badawczych”, 13(3).

Sidman C. (2015), Foreword [w:] D.M. Freedman, M.R. Nutting, Equity Crowdfunding for Investors: A Guide to Risks, Returns, Regulations, Funding Portals, Due Diligence, and Deal Terms, Wiley \& Sons, Hoboken (N.J.).

Silverman D. (2008), Prowadzenie badań jakościowych, tłum. J. Ostrowska, Wydawnictwo Naukowe PWN, Warszawa.

Solemon B., Ariffin I., Din M., Anwar R. (2013), A Review of the Uses of Crowdsourcing in Higher Education, „International Journal of Asian Social Science”, 3(9).

Statystyki konkursów 2016 (2017), Narodowe Centrum Nauki, https://ncn.gov.pl/sites/default/ files/pliki/NCN_statystyki_2016.pdf [dostęp: 16.11.2017].

UKIE Crowd Funding Report: A Proposal to Facilitate Crowd Funding in the UK (2012), The Association for UK Interactive Entertainment, London.

[www 1] http://crowdfunding.pl/crowdfunding-faq/ [dostęp: 6.11.2017].

[www 2] https://polakpotrafi.pl/ [dostęp: 6.11.2017].

[www 3] https://docs.google.com/document/d/1PEQrxJuLUu_Dl5uarE98TLoDAaRZOgIKEA 16-nhAa5k/edit\# [dostęp: 7.11.2017].

[www 4] https://www.siepomaga.pl/ [dostęp: 6.11.2017].

[www 5] https://wspieram.to/TajemniceEgipskichGrobowcow [dostęp: 6.11.2017].

[www 6] https://polakpotrafi.pl/projekt/ksiazka-pokolenie-erasmusa [dostęp: 6.11.2017].

[www 7] https://polakpotrafi.pl/projekt/praktyka-teoretyczna?utm_source=search [dostęp: $6.11 .2017]$

[www 8] https://experiment.com/ [dostęp: 6.11.2017].

[www 9] https:/experiment.com/projects/how-do-companies-repair-their-reputation-after-scandals?s=discover [dostęp: 6.11.2017].

[www 10] https://www.givecampus.com/schools/MissouriStateUniversity/msu-chorale-inauguration2017 [dostęp: 6.11.2017].

[www 11] https://crowdfund.berkeley.edu/project/805 [dostęp: 6.11.2017].

[www 12] https://uw.useed.net/projects/822/home [dostęp: 6.11.2017]. 